\section{Triazine Compound as Copolymerized Antibacterial Agent in Adhesive Resins}

Priscila Raquel Schiroky ${ }^{1}$, Vicente Castelo Branco Leitune ${ }^{1}$, Isadora Martini Garcia', Fabrício Aulo Ogliari², Susana Maria Werner Samuel ${ }^{1}$, Fabrício Mezzomo Collares ${ }^{1}$
'Dental Materials Laboratory, Conservative Dentistry Department, Dental School, UFRS - Universidade Federal do Rio Grande do Sul, Porto Alegre, RS, Brazil ${ }^{2} \mathrm{~S}$ chool of Engineering Materials, UFPel - Universidade Federal de Pelotas, Pelotas, RS, Brazil

Correspondence: Fabrício Mezzomo Collares, Rua Ramiro Barcelos, 2492, Rio Branco, 90035-003 Porto Alegre, RS, Brasil. Tel: +55-51-3308-5198. e-mail: fabricio.collares@ufrgs.br
The aim of this study was to formulate and evaluate an experimental adhesive resin with the addition of 1,3,5-triacryloylhexahydro-1,3,5-triazine at different concentrations. Experimental adhesive resins were obtained by mixing 50\% wt bisphenol A glycol dimethacrylate (BisGMA), 25\% wt triethylene glycol dimethacrylate (TEGDMA), 25\% wt 2-hydroxyethyl methacrylate (HEMA) and photoinitiator system. The triazine compound was added in 1, 2.5 and 5\% wt to a base adhesive resin and one group remained with no triazine as control group. The experimental adhesive resins were analyzed for antibacterial activity $(n=3)$, degree of conversion $(n=3)$ and softening in solvent $(n=3)$. Data distribution was evaluated by Kolmogorov-Smirnov test, paired t test, one-way ANOVA and Tukey's with a 0.05 level of significance. All groups with added triazine compound showed antibacterial activity against Streptococcus mutans $(\mathrm{p}<0.05)$. All groups achieved more than 70\% degree of conversion, but there was no difference in this chemical property ( $>>0.05)$. The initial Knoop hardness was higher in 2.5 and $5 \%$ wt groups $(p<0.05)$ and both groups present lower percentage variation of Knoop hardness after solvent degradation. The present study formulated an antibacterial adhesive resin with a non-releasing agent able to copolymerize with the comonomeric blend, improving the restorative material's properties.
Key Words: dentine-bonding agents, dental caries, antibacterial agents.

\section{Introduction}

The longevity of tooth restorations depends on many factors, like the patient-related variables (e.g. bruxism and caries risk) (1), the technique-sensitive procedure (2) and aspects related to the materials' properties $(3,4)$. Biofilm accumulation at tooth/restoration interface may lead to recurrent caries, which is responsible for $60 \%$ of restoration replacements in the typical dental practice (5). Thus, adhesive systems with antibacterial and nonantibacterial releasing agents have been proposed to reduce biofilm formation as an attempt to reduce the susceptibility to caries disease (6). Although there is no evidence of antibacterial adhesives effectiveness in the prevention of caries disease, they could benefit conservative dental treatments (6).

An adequate cavity seal is essential to inactivate the residual bacteria and to stop lesion progress in a minimally invasive dentistry approach (7). However, with the use of antibacterial releasing agent, it is impossible to control the release from the comonomeric blend. The antimicrobial effect can decrease over time and the process may reduce interface stability, turning the material prone to degradation, and increase biofilm accumulation and toxicity (6). The incorporation of antibacterial monomers able to copolymerize the methacrylate with the resin matrix has been studied $(8,9)$ to maintain a post-curing antibacterial effect for the adhesive and a reliable cavity seal.

1,3,5-triazine derivate compounds also present antimicrobial activity $(10,11)$, showing more selective antibacterial property against gram-positive pathogens (12). Recently, an experimental orthodontic adhesive resin containing 1,3,5 triacryloylhexahydro-1,3,5-triazine significantly reduced Streptococcus mutans growth (13), a bacteria positively correlated with baseline and increment caries (14). 1,3,5-triacryloylhexahydro-1,3,5-triazine is a methacrylate antibacterial compound, with three aliphatic double bonds $(\mathrm{C}=\mathrm{C})$. Because of this availability to copolymerize, this compound has been used to synthesize adhesive resins with better chemical and physical properties, like resistance to solvent degradation and bond strength $(13,15)$. Nevertheless, the addition of high triazine concentrations may compromise the wettability to dentine (16). Therefore, low amounts are required, which does not result in an antibacterial activity. However, to the best of the authors' knowledge, there are no reports on the use of 1,3,5-triacryloylhexahydro-1,3,5-triazine in adhesive resins for tooth restoration. The aim of this study was to formulate and evaluate an experimental adhesive resin with the addition of 1,3,5-triacryloylhexahydro-1,3,5-triazine 
at different concentrations. The tested hypothesis was that the addition of triazine compound does not influence adhesive resin properties.

\section{Material and Methods}

\section{Formulation of Experimental Adhesive Resins}

Experimental adhesive resins were obtained by mixing 50\% wt bisphenol A glycol dimethacrylate (BisGMA), 25\% wt triethylene glycol dimethacrylate (TEGDMA) and 25\% wt 2-hydroxyethyl methacrylate (HEMA). Camphorquinone and ethyl 4-dimethylaminobenzoate were added at $1 \% \mathrm{~mol}$ as photoinitiator system, according to the mols of used monomers. The 1,3,5-triacryloylhexahydro-1,3,5-triazine (Fig. 1) was added in 1, 2.5 and 5\% wt and the control group remained with no triazine. Reagents were hand mixed and sonicated for $180 \mathrm{~s}$. The light source device used for photoactivation for all tests was Radii Cal $(1200 \mathrm{~mW} /$ $\mathrm{cm}^{2}$, SDI, Bayswater, Victoria, Australia). All materials were purchased from Aldrich Chemical Co. (St. Louis, MI, USA).

\section{Direct Contact Inhibition (DCl)}

To determine the antibacterial activity, 3 cylindrical samples of each group $3.0 \mathrm{~mm}$ diameter and $1.0 \mathrm{~mm}$ high were produced. The specimens were submitted to hydrogen peroxide plasma sterilization. Streptococcus mutans (OMZ175) was grown aerobically in brain heart infusion (BHI) broth (HiMedia Laboratories Pvt. Ltd, Mumbai, India) at $37{ }^{\circ} \mathrm{C}$. The cells were harvested by centrifugation and re-suspended in fresh medium. Inocula were prepared by adjusting the cell suspension to a predetermined optical density (OD) of 0.5 at $550 \mathrm{~nm}$. Each specimen was placed in a well of a sterile 96 -well plate with $300 \mu \mathrm{L} \mathrm{BHI} \mathrm{broth,}$ and inoculated with $20 \mu \mathrm{L}$ of the Streptococcus mutans suspension. As negative control, three sets of wells containing non-inoculated fresh medium $(300 \mu \mathrm{L})$ were used. Immediately after the placement of inocula and after $24 \mathrm{~h}, 90 \mu \mathrm{L}$ of each well content were diluted in saline to

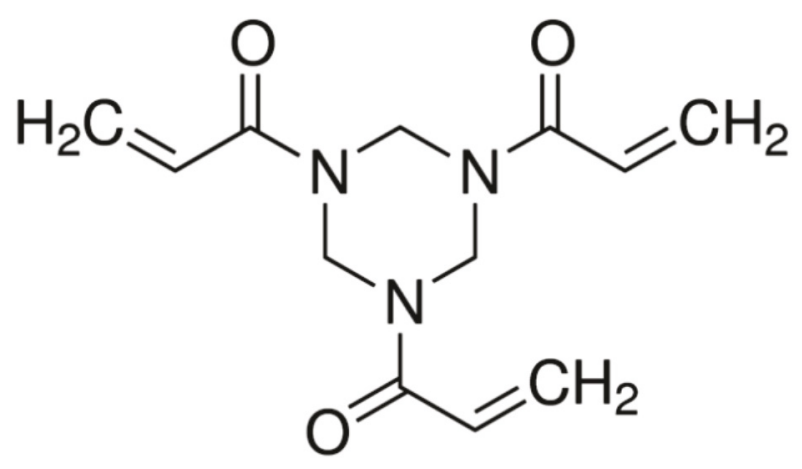

Figure 1. Chemical structure of 1.3.5-triacryloylhexahydro-1.3.5triazine.
$10^{-8}$. The $10^{-1}, 10^{-3}, 10^{-6}$ and $10^{-8}$ dilutions were plated on BHI Agar (HiMedia Laboratories) using $25 \mu \mathrm{L}$ aliquots of each dilution in duplicate. The plates were incubated at $37^{\circ} \mathrm{C}$ for $24 \mathrm{~h}$, in anaerobic conditions. Next, the colonies were visually counted, scaled by dilution factors and then transformed into colony forming units (CFUs) per milliliter. The experiment was performed according to a previous study (17).

\section{Softening in Solvent}

To assess the softening in solvent, the specimens $(5.0 \mathrm{~mm}$ in diameter and $1.0 \mathrm{~mm}$ thick) of each experimental adhesive resin $(n=3)$ were embedded in acrylic resin and polished with silicon carbide sandpapers $(600,1000,1200$ and 2000 granulation) and felt disks saturated with alumina suspension (alumina, $0.5 \mu \mathrm{m}$; Arotec, Cotia, SP, Brazil). Using a digital microhardness tester (HMV 2, Shimadzu, Tokyo, Japan), five indentations ( $10 \mathrm{~g} / 5 \mathrm{~s}) 100 \mu \mathrm{m}$ apart from each other were performed and the initial microhardness values (KHN1) were recorded. Specimens were then subjected to softening in absolute ethanol for $2 \mathrm{~h}$ at $37{ }^{\circ} \mathrm{C}$ and the microhardness values were measured again (KHN2). The percent difference was calculated according to a previous study (18).

\section{Degree of Conversion}

The degree of conversion was evaluated by Fourier transform infrared spectroscopy (FTIR) with a Vertex 70 (Bruker Optics, Ettlingen, Germany) spectrometer equipped with an attenuated total reflectance device (Platinum ATR-QL; Bruker Optics) composed of a horizontal diamond crystal with a $45^{\circ}$ mirror angle. A support was used to fix the light-curing unit at a standard distance of $1 \mathrm{~mm}$ from the sample for photoactivation. Opus software (Bruker Optics) was used, with a Blackman-Harris 3-Term apodization in a range of 4000 to $400 \mathrm{~cm}^{-1}$ and 64 scans at $4 \mathrm{~cm}^{-1}$ resolution. The samples $(n=3)$ were directly dispensed onto the diamond crystal and a spectrum was obtained prior to photoactivation and immediately after photoactivation for $20 \mathrm{~s}$. The degree of conversion was calculated as in a previous study (18).

\section{Statistical Analysis}

Data distribution was evaluated by the KolmogorovSmornov test. UFC and degree of conversion The values were analyzed with one-way ANOVA and Tukey's post hoc test. For softening in ethanol analysis, paired t-test (KHN1 and KHN2) and a one-way ANOVA and Tukey's post hoc $(\triangle K H N \%)$ were used. A level of significance of 0.05 was considered for all tests.

\section{Results}

All groups with triazine showed a significant decrease in 
bacterial growth when compared to positive and negative controls $(p<0.05)$. The values of colony forming units (CFUs) per milliliter are shown in Figure 2.

The 2.5\% triazine group presented a KHN1 of 19.1, the $5 \%$ group a KHN 1 of 18.9 and these values were significantly higher than the KNH1 of control and 1\% groups $(\mathrm{p}<0.05)$. The microhardness values after immersion in ethanol were lower than the initial ones for all groups $(p<0.05)$. The percent difference between KHN1 and KHN2 $(\triangle K H N)$ was lower in the $2.5 \%$ and $5 \%$ groups compared to the other groups $(\mathrm{p}<0.05)$. All microhardness values and percentage difference between KHN1 and KHN2 ( $\triangle K H N)$ are in Table 1.

The mean degree of conversion values are in Table 1. All groups achieved values above $70 \%$ and there was no statistically significant difference among the groups ( $>00.05)$.

\section{Discussion}

The development of an antibacterial adhesive is supposed to allow the reduction of biofilm accumulation at tooth/restoration interface without the disadvantages of releasing compounds or inorganic fillers from the resin matrix (6). The current trend involves the use of antibacterial monomers to create a more stable resin and long-lasting marginal sealing (19). The present study developed an experimental adhesive resin with three concentrations of 1,3,5-triacryloylhexahydro-1,3,5-triazine. All adhesives with this compound presented antibacterial activity and the resistance to solvent degradation improved from $2.5 \% \mathrm{wt}$ antibacterial monomer addition. Thus, the null hypothesis must be rejected.

The experimental adhesive resins containing the triazine compound inhibited Streptococcus mutans growth in

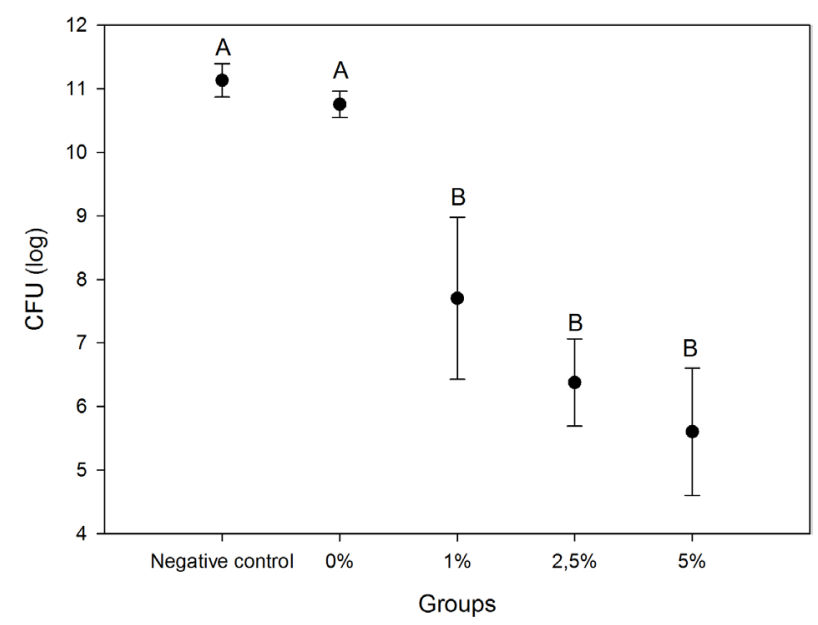

Figure 2. Mean and standard deviation of microbiological analysis in CFU (log). Different capital letters indicate statistically significant difference $(\mathrm{p}<0.05)$. all three concentrations $(1 \%, 2.5 \%$ and $5 \%)$, reducing CFU compared to the positive and negative controls $(p<0.05)$. The used triazine compound showed better results at lower concentrations than other antibacterial able to copolymerize, like benzotriazol, which achieved antibacterial effect only at 5\% wt (20). Studies that assessed the antibacterial activity of triazine in bonding materials also showed reduced bacterial growth against Streptococcus mutans after direct contact with the specimens $(13,15)$. The antibacterial mechanism is probably via disruption of bacteria's membrane integrity, as this compound mimics antimicrobial peptides (AMPs) secreted by immune system when infected by antimicrobials (12). Triazine compound is detected by the receptor structure due to its positive charge and lipophilic structure (12), fitting in a 3D structural model pre-defined by the receptor (21). Regarding the duration of the antibacterial effect, triazine is an antibacterial monomer that copolymerizes with methacrylate resin monomers $(13,15)$. This copolymerization provides an immobilization of the antibacterial component, which prevents its leaching that could result in a porous material, with low physical and chemical properties (6), beyond the loss of marginal sealing. This study did not evaluate the antibacterial effect after a long period. Nevertheless, it was previously shown that the copolymerization process is responsible for the inhibition bacteria growth in contact with the adhesive for at least six months after polymerization using other antibacterial monomers (methacryloxyl ethylcetyldimethylammonium chloride (DMAE-CB)) (9). Then, it is expected that the triazine compound also presents such behavior with time.

It was observed that there was no difference $(p>0.05)$ in degree of conversion among the groups. This finding indicates that the addition of triazine has no adverse influence on the curing process of BisGMA/TEGDMA/ HEMA-based adhesive resin, in accordance with the results reported for a BisGMA/TEGDMA-based experimental orthodontic adhesive (13). Triazine is a tri-functional monomer, presenting three carbon double bonds in the

Table 1. Mean ( $₫$ standard deviation) degree of conversion (DC), initial microhardness (KHN1), microhardness after solvent immersion (KHN2) and percent difference between KHN1 and KHN2 ( $\triangle \mathrm{KHN} \%)$

\begin{tabular}{lcccc}
\hline Groups & DC\% & KHN1 & KHN2 & $\Delta$ KHN\% \\
\hline $0 \%$ & $72.6( \pm 0.7)^{\mathrm{A}}$ & $12.2( \pm 1.7)^{\mathrm{Ba}}$ & $2.8( \pm 0.2)^{\mathrm{b}}$ & $73.7( \pm 3.7)^{\mathrm{B}}$ \\
$1 \%$ & $73.0( \pm 0.9)^{\mathrm{A}}$ & $12.4( \pm 0.3)^{\mathrm{Ba}}$ & $3.3( \pm 0.5)^{\mathrm{b}}$ & $76.6( \pm 4.7)^{\mathrm{B}}$ \\
$2.5 \%$ & $71.8( \pm 0.3)^{\mathrm{A}}$ & $19.1( \pm 2.0)^{\mathrm{Aa}}$ & $9.7( \pm 0.2)^{\mathrm{b}}$ & $48.8( \pm 5.6)^{\mathrm{A}}$ \\
$5 \%$ & $71.7( \pm 0.3)^{\mathrm{A}}$ & $18.9( \pm 1.2)^{\mathrm{Aa}}$ & $8.0( \pm 0.8)^{\mathrm{b}}$ & $57.4( \pm 8.3)^{\mathrm{A}}$ \\
\hline
\end{tabular}

Different capital letters in same column and different small letters in same row indicate statistically significant difference $(p<0.05)$. 
1,3,5 positions (Fig. 1) and the addition of triazine could increase double bond conversion (13). However, the FIIR analysis underestimates the degree of conversion values because it is possible that one of the methacrylate groups per molecule reacts and links as a pendant group (22). Despite not having changed the degree of conversion, the triazine's structure probably resulted in a higher branched polymer until 1\% wt and higher crosslink material from $2.5 \%$ wt., as the Knoop hardness values were improved from this concentration on. Along with the elution of the antibacterial agent, the release of unreacted monomers due to a lower degree of conversion could negatively affect adhesive properties and stimulate polymer degradation (23). In this study, all groups achieved more than 50\% degree of conversion, corroborating previous studies (24).

The adhesive resins with $2.5 \% \mathrm{wt}$ and $5 \%$ wt of triazine addition showed a higher initial Knoop hardness. Besides that, from $2.5 \%$ wt on, the resistance to solvent degradation was improved. This is an advantage among antibacterial adhesives, as it was observed that other adhesives with antibacterial fillers could not present this result (18). In this study, although the materials presented no statistical difference in degree of conversion, the polymer chains may have been organized differently. The softening in ethanol assay is an indirect method to estimate the polymer crosslink density (25). Highly crosslinked polymers are more resistant to solvent degradation due to the closer polymer chains (26), while more linear polymers are prone to have the chains overtaken by the forces of polymer chains with the solvent molecules (26). In this study, these two triazine compound concentrations probably led to a more crosslinked polymer compared to control and 1\% wt groups, creating a restorative material less prone to degradation over time. Besides that, it was shown that by the addition of antibacterial monomers, not only the resistance to solvent degradation is improved, but the bond strength is usually not altered (8). In addition to develop an adhesive with antibacterial activity, these findings suggest that the proposed material could be more stable and, consequently, an alternative for stablishing an adequate marginal sealing and improve protection against the biofilm formation and recurrent caries.

Composite materials favor the biofilm formation due to surface roughness and component release associated to the non-antibacterial property. In the present study, an antibacterial adhesive resin was formulated with a nonreleasing agent able to copolymerize with the comonomeric blend, improving the restorative material.

\section{Resumo}

0 objetivo desse estudo foi desenvolver e avaliar a adição de 1,3,5-triacryloylhexahydro-1,3,5-triazine a uma resina adesiva experimental em diferentes concentrações. Resinas adesivas experimentais foram obtidas a partir da mistura de $50 \%$ em peso de bisphenol A glycol dimethacrylate (BisGMA), 25\% em peso de triethylene glycol dimethacrylate (TEGDMA), 25\% em peso de hidroxietil metacrilato (HEMA) e sistema fotoiniciador. 0 composto de triazina foi adicionado em proporções de 1; 2,5 e 5\% em peso a resina adesiva base e um grupo permaneceu sem a adição do composto de triazina como grupo controle. As resinas adesivas experimentais foram analisadas por atividade antibacteriana $(n=3)$, grau de conversão $(n=3)$ e degradação em solvente $(n=3)$. A distribuição dos dados foi avaliada por teste de KolmogorovSmirnov, teste t pareado, ANOVA de uma via e Tukey, considerando nivel de significância de 5\%. Todos os grupos com adição de composto de triazina demonstraram atividade antibacteriana contra Streptococcus mutans $(p<0,05)$. Todos os grupos atingiram mais de $70 \%$ de grau de conversão, mas não houve diferença estatística para essa propriedade química $(p>0,05)$. A dureza Knoop inicial foi maior para os grupos com 2,5 e $5 \%$ de triazina $(p<0,05)$ e ambos os grupos apresentaram menor variação percentual de dureza Knoop após degradação em solvente. No presente estudo, foi produzida uma resina adesiva antibacteriana com agente sem liberação para o meio, capaz de copolimerizar com a blenda comonomérica, melhorando as propriedades do material restaurador.

\section{Acknowledgements}

The authors gratefully acknowledge CAPES (Coordenação de Aperfeiçoamento de Pessoal de Nivel Superior) and CNPq (Conselho Nacional de Desenvolvimento Científico e Tecnológico) for the scholarchip of PRS and IMG, respectively. The authors declare no potential conflicts of interest with respect to the authorship and/or publication of this study.

\section{References}

1. van de Sande FH, Opdam NJ, Rodolpho PA, Correa MB, Demarco FF, Cenci MS. Patient risk factors' influence on survival of posterior composites. J Dent Res 2013;92:78S-83S.

2. Nedeljkovic I, Teughels W, De Munck J, Van Meerbeek B, Van Landuyt $\mathrm{KL}$. Is secondary caries with composites a material-based problem? Dent Mater 2015;31:e247-277.

3. Collares FM, Rodrigues SB, Leitune VC, Celeste RK, Borba de Araujo F, Samuel SM. Chlorhexidine application in adhesive procedures: a metaregression analysis. J Adhes Dent 2013;15:11-18.

4. da Veiga AM, Cunha AC, Ferreira DM, da Silva Fidalgo TK, Chianca $T K$, Reis $K R$, et al.. Longevity of direct and indirect resin composite restorations in permanent posterior teeth: A systematic review and meta-analysis. J Dent 2016.

5. Mjor IA. The reasons for replacement and the age of failed restorations in general dental practice. Acta Odontol Scand 1997;55:58-63.

6. Cocco AR, Rosa WL, Silva AF, Lund RG, Piva E. A systematic review about antibacterial monomers used in dental adhesive systems: Current status and further prospects. Dent Mater 2015;31:1345-1362.

7. Maltz M, Henz SL, de Oliveira EF, Jardim JJ. Conventional caries removal and sealed caries in permanent teeth: a microbiological evaluation. J Dent 2012;40:776-782.

8. Imazato S, Kinomoto $Y$, Tarumi H, Ebisu S, Tay FR. Antibacterial activity and bonding characteristics of an adhesive resin containing antibacterial monomer MDPB. Dent Mater 2003;19:313-319.

9. Xiao YH, Ma S, Chen JH, Chai ZG, Li F, Wang YJ. Antibacterial activity and bonding ability of an adhesive incorporating an antibacterial monomer DMAE-CB. J Biomed Mater Res B Appl Biomater 2009;90:813-817.

10. Bhat HR, Singh UP, Thakur A, Kumar Ghosh S, Gogoi K, Prakash $A$, et al. Synthesis, antimalarial activity and molecular docking of hybrid 4-aminoquinoline-1,3,5-triazine derivatives. Exp Parasitol 2015;157:59-67.

11. Singh B, Bhat HR, Kumawat MK, Singh UP. Structure-guided discovery of 1,3,5-triazine-pyrazole conjugates as antibacterial and antibiofilm agent against pathogens causing human diseases with favorable metabolic fate. Bioorg Med Chem Lett 2014;24:3321-3325.

12. Zhou C, Min J, Liu Z, Young A, Deshazer H, Gao T, et al.. Synthesis and biological evaluation of novel 1,3,5-triazine derivatives as 
antimicrobial agents. Bioorg Med Chem Lett 2008;18:1308-1311.

13. Altmann AS, Collares FM, Ogliari FA, Samuel SM. Effect of methacrylated-based antibacterial monomer on orthodontic adhesive system properties. Am J Orthod Dentofacial Orthop 2015;147:S82-87.

14. Kirstila $V$, Hakkinen $P$, Jentsch $H$, Vilja $P$, Tenovuo J. Longitudinal analysis of the association of human salivary antimicrobial agents with caries increment and cariogenic micro-organisms: a two-year cohort study. J Dent Res 1998;77:73-80.

15. Altmann AS, Collares FM, Leitune VC, Arthur RA, Takimi AS, Samuel SM. In vitro antibacterial and remineralizing effect of adhesive containing triazine and niobium pentoxide phosphate inverted glass. Clin Oral Investig 2016.

16. Wagner A, Belli $R$, Stotzel C, Hilpert A, Muller FA, Lohbauer U. Biomimetically- and hydrothermally-grown HAp nanoparticles as reinforcing fillers for dental adhesives. J Adhes Dent 2013;15:413-422.

17. Degrazia FW, Leitune VC, Garcia IM, Arthur RA, Samuel SM, Collares FM. Effect of silver nanoparticles on the physicochemical and antimicrobial properties of an orthodontic adhesive. J Appl Oral Sci 2016;24:404-410.

18. Garcia IM, Leitune VC, Kist TL, Takimi A, Samuel SM, Collares FM. Quantum dots as nonagglomerated nanofillers for adhesive resins. J Dent Res 2016; 95:1401-1407.

19. Cheng L, Weir MD, Zhang K, Arola DD, Zhou X, Xu HH. Dental primer and adhesive containing a new antibacterial quaternary ammonium monomer dimethylaminododecyl methacrylate. J Dent 2013;41:345355.

20. Centenaro CC, Rostirolla FV, Leitune VC, Parolo CF, Ogliari FA, Samuel $\mathrm{SM}$, et al.. Influence of addition of 2-[3-(2H-benzotriazol-2-YL)- 4-hydroxyphenyl] ethyl methacrylate to an experimental adhesive system. Acta Odontol Latinoam 2015;28:72-78.

21. Lewis SN, Garcia Z, Hontecillas R, Bassaganya-Riera J, Bevan DR. Pharmacophore modeling improves virtual screening for novel peroxisome proliferator-activated receptor-gamma ligands. J Comput Aided Mol Des 2015;29:421-439.

22. Jancar J, Wang W, DiBenedetto AT. On the heterogeneous structure of thermally cured bis-GMA/TEGDMA resins. J Mater Sci Mater Med 2000;11:675-682.

23. Ferracane JL. Hygroscopic and hydrolytic effects in dental polymer networks. Dent Mater 2006;22:211-222.

24. Gaglianone LA, Lima AF, Goncalves LS, Cavalcanti AN, Aguiar FH, Marchi GM. Mechanical properties and degree of conversion of etchand-rinse and self-etch adhesive systems cured by a quartz tungsten halogen lamp and a light-emitting diode. J Mech Behav Biomed Mater 2012;12:139-143.

25. Schneider LF, Moraes RR, Cavalcante LM, Sinhoreti MA, CorrerSobrinho L, Consani S. Cross-link density evaluation through softening tests: effect of ethanol concentration. Dent Mater 2008;24:199-203.

26. Rodrigues SB, Collares FM, Leitune VC, Schneider LF, Ogliari FA, Petzhold $\mathrm{CL}$, et al.. Influence of hydroxyethyl acrylamide addition to dental adhesive resin. Dent Mater 2015;31:1579-1586.

Received October 13, 2016 Accepted February 7, 2017 